\title{
Evaluation of pelvic floor muscles and sexual function in pregnant women: cross-
}

\section{sectional research}

\author{
A valiação dos músculos do assoalho pélvico e da função sexual em gestantes: pesquisa transversal \\ Evaluación de los músculos del suelo pélvico y la función sexual en mujeres embarazadas:
}

investigación transversal

\author{
Emanuela Izania dos Reis Santana \\ ORCID: https://orcid.org/0000-0003-4454-1119 \\ Universidade Federal do Delta do Parnaíba, Brazil \\ E-mail: emanuhreis@gmail.com \\ Larissa Maria da Silva Borgéa \\ ORCID: https://orcid.org/0000-0002-0665-8319 \\ Universidade Federal do Delta do Parnaíba, Brazil \\ E-mail: larissaborgea@ hotmail.com \\ Muriel Miranda de Freitas \\ ORCID: https://orcid.org/0000-0002-1704-4531 \\ Universidade Federal do Delta do Parnaíba, Brazil \\ E-mail: murielfisiophb@gmail.com \\ Laiane Santos Eufrásio \\ ORCID: https://orcid.org/0000-0003-0578-7140 \\ Universidade Federal do Rio Grande do Norte, Brazil \\ E-mail: laieufrasio@ufrn.edu.br \\ Lysnara Rodrigues Barros Lial \\ ORCID: https://orcid.org/0000-0002-6797-9829 \\ American Hospital Dubai, United Arab Emirates \\ E-mail: lysnara@hotmail.com \\ Nara Calaça Ribeiro \\ ORCID: https://orcid.org/0000-0003-0266-0144 \\ Hospital Estadual Dirceu Arcoverde, Brazil \\ E-mail: naracalacaribeiro@gmail.com \\ Mona Indianara da Costa Aragão \\ ORCID: https://orcid.org/0000-0003-2557-9912 \\ Universidade Federal do Delta do Parnaíba, Brazil \\ E-mail:monna.aragao@gmail.com \\ Sávia Francisca Lopes Dias \\ ORCID: https://orcid.org/0000-0002-4490-8331 \\ Universidade Federal do Delta do Parnaíba, Brazil \\ E-mail: saviadias@ufpi.edu.br
}

\begin{abstract}
The aim of this study was to evaluate pelvic floor functionality and sexual function in pregnant women. The study was characterized as a descriptive and transversal research. The population consisted of 19 pregnant women, living in Parnaíba/PI. The women's assessment instruments were the evaluation and identification form that contained sociodemographic data, clinical history, obstetric and urogynecological data; the NEW PERFECT scheme was used to assess the functionality of the pelvic floor muscles and the Female Sexual Function Index (FSFI) to assess sexual function. Mean age was 25.95 ( \pm 3.54 ) years, mean pelvic floor muscle strength was $2.47( \pm 1.28)$; resistance was 4.31 $( \pm 2.99)$ seconds; the number of repetitions of the contractions maintained was $2.63( \pm 1.6)$ times; and rapid contractions were $5.05( \pm 2.87)$ contractions. Sexual function according to the FSFI totaled a score of 25.61. In this study, it was possible to infer important deficiencies and limitations regarding strength, coordination, control and activation of the pelvic floor muscles. As in the sexual function domain, the FSFI result indicates possible dysfunctions with an emphasis on the hypoactivity of sexual desire.
\end{abstract}

Keywords: Pregnant women; Pelvic floor; Sexuality.

\section{Resumo}

O objetivo deste estudo foi avaliar a funcionalidade do assoalho pélvico e a função sexual em gestantes. O estudo caracterizou-se como uma pesquisa descritiva e transversal. A população foi composta por 19 gestantes, residentes em Parnaíba / PI. Os instrumentos de avaliação das mulheres foram a ficha de avaliação e identificação que continha dados 
sociodemográficos, história clínica, dados obstétricos e uroginecológicos; o esquema NEW PERFECT foi utilizado para avaliar a funcionalidade dos músculos do assoalho pélvico e o Índice de Função Sexual Feminina (FSFI) para avaliar a função sexual. A média de idade foi $25,95( \pm 3,54)$ anos, a força muscular do assoalho pélvico teve média de $2,47( \pm 1,28)$; a resistência foi de 4,31 $( \pm 2,99)$ segundos; o número de repetições das contrações mantidas foi de 2,63 $( \pm 1,6)$ vezes; e as contrações rápidas foram de 5,05 $( \pm 2,87)$ contrações. A função sexual de acordo com o FSFI totalizou uma pontuação de 25,61. Neste estudo foi possível inferir deficiências e limitações importantes quanto à força, coordenação, controle e ativação dos músculos do assoalho pélvico. Assim como no domínio função sexual, o resultado do FSFI indica possíveis disfunções com ênfase na hipoatividade do desejo sexual.

Palavras-chave: Gestantes; Assoalho pélvico; Sexualidade.

\section{Resumen}

El objetivo de este estudio fue evaluar la funcionalidad del suelo pélvico y la función sexual en mujeres embarazadas. El estudio se caracterizó por ser una investigación descriptiva y transversal. La población estuvo conformada por 19 mujeres embarazadas, residentes en Parnaíba / PI. Los instrumentos de evaluación de las mujeres fueron el formulario de evaluación e identificación que contenía datos sociodemográficos, historia clínica, datos obstétricos y uroginecológicos; Se utilizó el esquema NEW PERFECT para evaluar la funcionalidad de los músculos del piso pélvico y el Índice de Función Sexual Femenina (FSFI) para evaluar la función sexual. La edad media fue 25,95 $( \pm 3,54)$ años, la fuerza muscular media del suelo pélvico fue $2,47( \pm 1,28)$; la resistencia fue de $4,31( \pm 2,99)$ segundos; el número de repeticiones de las contracciones mantenidas fue de $2,63( \pm 1,6)$ veces; y las contracciones rápidas fueron 5,05 $( \pm 2,87)$ contracciones. La función sexual según la FSFI totalizó una puntuación de 25,61. En este estudio fue posible inferir importantes deficiencias y limitaciones en cuanto a fuerza, coordinación, control y activación de la musculatura del suelo pélvico. Al igual que en el dominio de la función sexual, el resultado de FSFI indica posibles disfunciones con énfasis en la hipoactividad del deseo sexual.

Palabras clave: Mujeres embarazadas; Suelo pélvico; Sexualidad.

\section{Introduction}

The pregnancy is an event considered biologically natural, however it is a period of important emotional vulnerability in which ambivalent feelings are experienced, in addition, it involves the need for restructuring in different dimensions, seeking adjustments, whether biological or psychic that vary according to the gestational age and from pregnant to pregnant. Thus, the gestational period can be experienced in different ways, depending on the emotional and physiological adaptations suffered by pregnant women (Da Silva Lima, Carmo, Neto, \& Cunha Pena, 2020)

Among the physiological adaptations, the hormonal changes directly affect the pelvic floor muscles (PFM), in particular, caused by estrogen (causes ligament laxity), progesterone (responsible for the decrease in smooth muscle tone) and relaxin hormones (causes ligamentous laxity, as well as impacts on the vaginal tissue, expanding the circumference of the vaginal lumen and increasing epithelial cells) (Martinez, Ferreira, \& Castro, 2014); changes in the cardiovascular system, with an increase in the total blood volume and greater flow directed to the uterus and kidneys; changes in the integumentary system with changes in skin, hair and skin oils and musculoskeletal adaptations resulting from fetal and uterine growth. In addition, there is an increase in body weight, generating upward and forward displacement of the center of gravity with consequent overload of the pelvis and pelvic floor, which are essential structures for urethral support, through mechanisms of urinary and fecal continence, in addition to functioning as support base for the baby and abdominal organs during pregnancy (Marnach et al., 2003).

The PF is a group of muscles, fascias and ligaments that are responsible for supporting the internal organs, especially the uterus, bladder, and rectum, and have a particular function during childbirth, and essential role in sexual function. The weakening of these muscles in the perineal area results in deficiencies of the gynecological system that interfere in sexual relations, generating discomfort and dissatisfaction, these are called female sexual dysfunctions, which can be classified mainly as: dysfunction of desire, excitement, and orgasm (Barreto, Mesquita, Junior, \& Gameiro, 2018).

Therefore, understanding that pregnancy and that the childbirth can bring about several changes in the woman's body, such as: reduced pelvic floor muscle strength and sexual dysfunctions (Barbosa, Carvalho, Martins, Calderon, \& Rudge, 2005), this study aimed to evaluate the functionality of the pelvic floor and the sexual function of pregnant women. 


\section{Methodology}

The study was characterized by being a descriptive and transversal research, being this carried out at the Universidade Federal do Delta do Parnaíba (UFDPar), Parnaíba/PI. The population consisted of pregnant women, residents of Parnaíba/PI. Volunteers were recruited through dissemination via social networks and leafleting at Basic Health Units in the region and at the UFDPar, Parnaíba/PI, in which they participated in a multidisciplinary Antenatal Health Education Course.

Initially, all women were informed about the research and invited to participate voluntarily, on that occasion they signed the Informed Consent Form. The study sample was the result of a non-probabilistic process, with a total of 23 women. The following inclusion criteria were adopted: (1) low-risk pregnant women (proven by medical report), between 18 and 37 years old, (2) residents in Parnaíba/PI, (3) second or third gestational trimesters, with no distinction between the same, (4) single fetus, (5) sign the free and informed consent form, (6) Participation in the multidisciplinary Antenatal Health Education Course. Pregnant women who refused to perform any of the steps of the physical therapy assessment were excluded from the study.

The instruments used for the evaluation were evaluation and identification form during pregnancy, which contained identification and socio-demographic data, clinical history, obstetrics and urogynecological data. The evaluation of the pelvic floor muscles (PFM) was performed through bidigital vaginal palpation, a valid technique widely used in the literature (Silva, 2020), according to the perception of contractile activity related to the Modified Oxford Scale (domains from zero to five, in which zero: absence of muscle response; 1: sketch of a non-sustained contraction; 2: presence of a low-intensity but sustained contraction; 3: moderate contraction, felt as an increase in intravaginal pressure, which compresses the examiner's fingers with small cranial elevation of the vaginal wall; 4: satisfactory contraction, which squeezes the examiner's fingers with elevation of the vaginal wall towards the pubic symphysis; 5: strong contraction, firm compression of the examiner's fingers with positive movement towards the symphysis pubic) (Driusso \& Beleza, 2018).

To quantify the intensity, duration and sustainment of the contraction, as well as the functional aspects of the PFM, the NEW PERFECT scheme was used, in which: $\mathrm{P}=$ Power (muscle strength), means the maximum voluntary contraction, measured by the Oxford scale ( 0 to 5$) ; \mathrm{E}=$ Endurance (maintenance of contraction), measures resistance and refers to the time in which it is possible to maintain the degree of muscle function achieved in Power, measured with a time of up to 10 seconds; $\mathrm{R}=\mathrm{Repetition}$ of contractions maintained, it is the number of repetitions in which it is possible to maintain the degree in Power during the time recorded in Endurance with intervals of 4 seconds of rest between each contraction, performed in up to 10 repetitions; F $=$ Fast (number of fast contractions of 1s), the PFM contraction and relaxation is performed vigorously and quickly with the deg ree in $\mathrm{P}$ in up to 10 contractions; $\mathrm{E}=$ elevation, observes the elevation of the vaginal wall during a maximum voluntary contraction, confirmed as present or absent; $\mathrm{C}=$ contractions, confirms if there is co-contraction of accessory muscles during a maximum voluntary contraction, being present or absent; $\mathrm{T}=$ timed, observes the involuntary PFM contraction during cough (Scagliusi et al., 2005).

For the evaluation of sexual function, the Female Sexual Function Index (FSFI) was used, being a multiple-choice questionnaire that assesses the domains desire, arousal, lubrication, orgasm, satisfaction and dyspareunia (Negri, 2016). The evaluation of the quality of sexual function took place in the last 4 weeks of the evaluation, through 19 questions addressed to pregnant women. The response classification is distributed into 5 items that, according to intensity, will assess and identify changes in sexual function. In the following protocol, the result is given in scores added according to each domain, and the options are scored from 0 to 5, according to the questioned function. When the scores for each domain are added, they are multiplied by a factor that homogenizes the influence of each domain, and, in the end, the total score is reached. The score is inverted only for questions related to pain (Magno, Fontes-Pereira, \& Nunes, 2011). Value of the scores for each domain range from 0 to 6 (except desire: minimum 1.2 and satisfaction: minimum 0.8 ) and the total score ranges from 2 to 36 . The higher the final score, the better the sexual function (Pacagnella, Vieira, Rodrigues, \& Souza, 2008). 
Data collection was performed by three evaluators, who performed prior training on standardization of the assessment under the guidance and supervision of a teacher who is a specialist in urogynecological physiotherapy and with vast professional technical experience. According to Silva et al. (2021), the PERFECT scheme performed by bidigital vaginal palpation presents greater reliability when two examiners perform the physical examination, in which the inter-examiner bidigital reliability was considered moderate for strength, resistance and fast contractions.

The project was submitted and approved by the Research Ethics Committee (REC) under opinion number 2,734,047. The anonymity of the participants was respected and guaranteed, ensuring their privacy regarding the data collected during the research, as governed by Resolution 466/12 / of the National Health Council. Participants who wished to leave the study were able to do so at their own discretion.

Data analysis was performed using Microsoft Office Excel 2015. First, there was a characterization of the sample using descriptive statistics regarding sociodemographic, clinical, urogynecological, anthropometric and sexual variables. Soon after, the tabulation of the results was presented through frequencies, by measures of central tendency (mean) and dispersion (standard deviation) followed by the elaboration of graphic data of the results.).

\section{Results}

Twenty-three pregnant women participated in this research, and 4 were excluded from the results, due to the lack of information in the evaluation form. Thus, a total of 19 were included in the study. The age ranged from 18 to 37 years, with a mean age of $25.95( \pm 3.54)$ years. Table 1 presents a characterization of sociodemographic data.

Table 1. Characterization of sociodemographic data of pregnant women $n=19$.

\begin{tabular}{ll}
\hline Variety & $\mathbf{n}(\%)$ \\
\hline Scholarity & $2(10,53)$ \\
Elementary School & $7(36,84)$ \\
High School & $7(36,84)$ \\
University Education & $3(15,79)$ \\
Post-Graduation & \\
\hline Profession & $6(31,58)$ \\
\hline Student & $9(42,10)$ \\
Labor & $5(26,32)$ \\
Not applicable & \\
\hline Monthly income (MI) & $9(47,37)$ \\
\hline 1 a 2 & $6(31,58)$ \\
3 a 4 & $1(5,26)$ \\
$\geq 4$ & $3(15,79)$ \\
Did not answer & \\
\hline Marrital Status & $7(36,84)$ \\
\hline Married & $11(57,90)$ \\
Stable union & $1(5,26)$ \\
Single & \\
\hline Race & $4(21,05)$ \\
\hline White & $13(68,42)$ \\
Brown & $2(10,53)$ \\
Black &
\end{tabular}

Source: Authors.

Table 2 shows the obstetric and anthropometric data of the women investigated. Of these, $73.68 \%$ had pain during pregnancy, $15.79 \%$ did not report pain and $10.53 \%$ had other symptoms (colic, heartburn, tiredness, difficulty sleeping, headache). Roughly $89.49 \%$ of pregnant women had support from their partner or family members. 
Table 2. Obstetric and anthropometric data of the women $n=19$.

\begin{tabular}{ll}
\hline Variety & $\mathbf{n}(\%)$ \\
\hline Complain/ & \\
Symptoms & $13(73,68)$ \\
\hline Pain & $4(15,79)$ \\
Pain free & $2(10,53)$ \\
Other symptoms & \\
\hline Planned pregnancy & $4(21,05)$ \\
\hline Yes & $15(78,95)$ \\
No & \\
\hline Desired pregnancy & $17(89,48)$ \\
\hline Yes & $1(5,26)$ \\
No & $1(5,26)$ \\
Did not answer & \\
\hline Partner/ Family & \\
Support & $17(89,47)$ \\
\hline Yes & $2(10,53)$ \\
No & \\
\hline Type of childbirth & \\
desired & $17(89,48)$ \\
\hline Vaginal/Normal & $1(5,26)$ \\
Cesarean & $1(5,26)$ \\
Did not answer & \\
\hline Obstetric follow-up & $14(73,68)$ \\
\hline Public & $3(15,79)$ \\
Private & $2(10,53)$ \\
Did not answer & \\
\hline
\end{tabular}

Source: Authors.

All 19 participants underwent obstetric follow-up during prenatal care. However, it is noteworthy that the pregnant women in this study had not yet completed their pregnancy and, therefore, continued to carry out these consultations. Among all participants, $89.48 \%$ had intended vaginal/normal delivery, 5.26\% cesarean delivery and 5.26\% did not respond. As for life habits, none of the women reported using alcohol daily. In the group of pregnant women, there was a significant increase in the Body Mass Index (BMI) with an average of 25.65 ( \pm 3.29$)$, which corresponds to overweight according to the World Health Organization classification.

Through the NEW PERFECT scheme, it was possible to assess the functionality of the pelvic floor muscles. In Power (P) the maximum voluntary contraction is graded using the Modified Oxford Scale, the mean of the investigated group was 2.47 $( \pm 1.28)$. According to this scale, grade 2 identifies the presence of a weak but sustained PFM contraction.

The Endurance $(\mathrm{E})$ refers to the time in which the participant manages to maintain the contraction in the degree of strength identified in $\mathrm{P}$, the sample mean was 4.31 ( \pm 2.99$)$ seconds; the mean number of Repetitions/Repetitions (R) of the sustained contractions was 2.63 ( \pm 1.6$)$ times; and the mean of Fast/Fast contractions (F) was 5.05 ( \pm 2.87$)$ contractions.

The Elevation (E) of the vaginal wall was present in $57.9 \%$ of the sample and absent in $42.1 \%$ and the Co-contraction (C) of accessory muscles was identified in all patients, of these $31.57 \%$ used the glutes to assist in the contraction and the others an association of adductors, rectus abdominis and other accessory muscles.

Other important aspects of the functional physical examination included: perineal body tone (normal 83.33\%; hypertonic $11.11 \%$ and hypotonic 5.55\%); perineal tension point (yes $11.11 \%$ and no $88.88 \%$ ); contraction symmetry (asymmetric 93.75\% and symmetric 6.25\%); presence of apnea during PFM contraction (yes 58.82\% and no 41.27\%); diastasis recti (present $68.42 \%$ and absent $31.57 \%$ ) and at least one episode of involuntary loss of urine in pregnancy at some point $(36.84 \%)$. 
The sexual function was assessed using the Female Sexual Function Index (FSFI) questionnaire, which analyzes sexual desire, arousal, vaginal lubrication, orgasm, satisfaction, and pain. In the investigated pregnant women, the FSFI totaled a score of 25.61. In Figure 1, it is possible to observe the scores for each domain of sexual function.

Figure 1. Scores of FSFI domains.

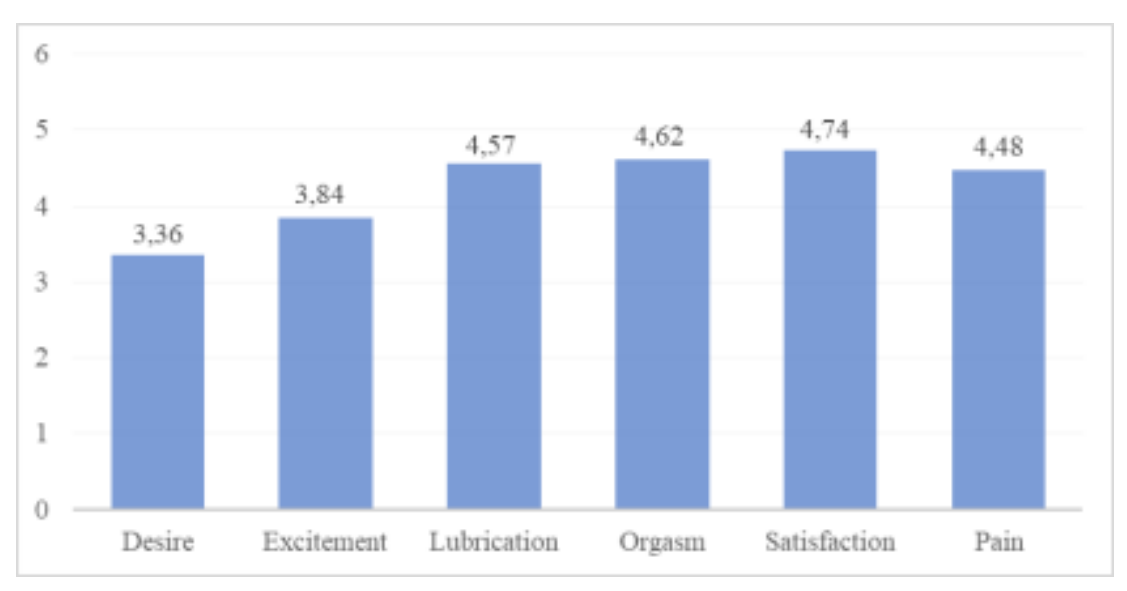

Source: Authors.

\section{Discussion}

The study population was very close in terms of sociodemographic conditions. Regarding the classification of pregnant women population, the most frequent self-declared race was brown, followed by white and black. This data can be attributed to the Brazilian racial characteristics and follow the pattern found by the study in Brazil (Gosch, Pereira, \& Mundoco, 2020) as well as the prevalence of pregnant women were among 20 and 23 years old. Regarding education, complete high school and complete higher education were predominant, and a percentage $(15.79 \%)$ had a postgraduate degree. This data is particularly important since it shows to which audience the research was applied to.

Pregnancy is a period of physical and psychological changes that, together with cultural, social, religious, and emotional influences, can impact the pelvic floor function, sexual behavior, and quality of life of these population (Franceschet, Sacomori, \& Cardoso, 2009). In this study, PFM strength was measured by manual bidigital palpation and function was assessed according to the PERFECT graduation scheme.

The manual test of the pelvic floor muscles is one of the most common options to assess these structures and it is one of the most sensitive method to investigate the strength and tone of the PFM. Furthermore, it is a simple tool and does not require expensive equipment (Laycock \& Jerwood, 2001). According to scientific evidence the PERFECT scheme demonstrates reliability and validity as a functional assessment tool for the PFM (Tibaek \& Dehlendorff, 2014).

The evaluated pregnant women presented, in the PF muscle strength criteria, an average degree of 2.47 ( \pm 1.28$)$, which, in the Modified Oxford Scale, identifies the presence of PF muscle contraction, weak, however sustained and no noticeable elevation. Authors in recent research on PFM function classified strength $\geq 4$ representing strong muscles and strength $\leq 3$ representing weak muscles. In addition, they also state that an effective contraction should result in an elevation of the PFM, which was not observed in $42.1 \%$ of the participants (Tosun et al., 2019; Sherburn \& Bø, 2005).

Adding this to the other PERFECT results, which include time to sustain the deficient contraction, insufficient number of sustained contractions, fast contractions, and the use of accessory muscles, perceived mainly using the glutes to assist in the contraction, the result of the functional assessment of the PFM of pregnant women demonstrates important deficiencies and 
limitations regarding the coordination, control, and activation of the PFM. According to Sherburn e Bø (2005), assessment of the function and strength of PFM is necessary to provide information on a woman's ability to contract the PF and to document changes in function and strength during the intervention. Therefore, will be possible to develop a specific and effective treatment plan (Herbert, 2009).

Given the physical changes during pregnancy, several biomechanical changes can occur on the pelvic muscles, one of them is urinary incontinence (UI) (Ashton-Miller \& DeLancey, 2014), a dysfunction that occurs mainly due to the overload on the pelvic floor muscles and the bladder organ (Slieker-ten et al., 2009), negatively affecting health and quality of the pregnant woman's life. In this research, UI did not affect most of the participants, perhaps this is due to the epidemiological profile of the investigated group, however it was still present, and the most frequent type was stress urinary incontinence (SUI).

During the assessment, it is possible to observe some changes that will identify dysfunctions. In this sense, the literature highlights as an important point to be evaluated during palpation the symmetry of the pelvic floor muscles contraction (Souza, Vasconcelos, Pires, Macena, \& Bastos, 2017). In this study, 93.75\% of the pregnant women were asymmetric in terms of PFM contraction. Another important aspect is the presence of apnea during PFM contraction, which may be associated with the use of accessory muscles (Souza, 2002). In this study, more than half of the pregnant women had apnea and all of them used accessory muscles.

Another condition observed during the evaluation was the diastasis recti, present in $68.42 \%$ of the evaluated pregnant women. During pregnancy, there is a stretch of the abdominal muscles, causing the separation of the rectus abdominis muscle bundles (diastasis of the rectus abdominis - DRA). The condition of DRA in pregnant women can produce musculoskeletal complaints, such as low back pain, possibly because of the decrease in the ability of the abdominal muscles to control the pelvis and lumbar spine, with respiratory difficulty and postural changes. Functional limitations may occur, such as inability to make independent transitions from supine to sitting, due to biomechanical and functional misalignment (Vanelli \& Silva, 2011).

Sexual activity during pregnancy has always been viewed with prejudice and taboos, this is mainly due to the lack of knowledge on the subject. During pregnancy, for a long time, sexual life was seen as inadequate, where the woman directed her libido to care for the family and, during this period, ended up excluding sex from her daily life (Leite et al., 2007).

It is a challenge to measure women's degree of sexual satisfaction. There are several variables that interact with each other (e.g., biological, psychological, physiological, cultural patterns) and that can influence the degree of final satisfaction (Pechorro, Diniz, \& Vieira, 2009). In the present study, it was possible to observe that the 19 pregnant women had sexual relations during the gestational period. However, this does not mean quality and satisfaction in these relationships. In their study, Costa et al. (2020) also reported that all women had sexual relations with their partners during the gestational period and that $85 \%$ of them stated that they recognized that the maintenance of sexual relations during the gestational period would not harm the baby. However, $93 \%$ of these women have never heard about the pelvic floor or know the importance of the perineum for women's health. Probably, if during pregnancy, women had more information regarding their bodies, they could seek specialized help to deal with all the changes in a more adequate way, thus being able to avoid some sexual dysfunctions and better quality and satisfaction in relationships.

Considering the subjectivity of female sexual response, the FSFI is one of the most appropriate instruments for this type of assessment, as it is practical for the application in field research. The FSFI evaluates the relative strength of each domain of sexual response and converts subjective measures into objective data, measurable and analyzable. The present study quantified the total FSFI score at 25.61 points. Latorre, Carmona, Bilck, Berghmans, \& Sperandio (2015), discussed the validity of the cutoff scores predictive of female sexual dysfunction (FSD) for the FSFI and concluded that the score of 26.55 was used in more than $84 \%$ of the studies, however, this value has been validated only in the US population. Even so, these values suggest greater attention to the possibility of DSF in the investigated pregnant women. This is because the FSFI was adapted to the Brazilian 
culture, showing significant reliability and validity, and can be included and used in studies of the sexual function of Brazilian pregnant women (Hentschel, Alberton, Capp, Goldim, \& Passos, 2007).

Regarding the FSFI domains, low values ranging between 4.74 and 3.36 with higher scores for satisfaction, pain (it is noteworthy that for the item pain are inverted values), orgasm and lubrication, and lower for desire and excitement. Baratella et al. (2021) also reported lower scores for desire and arousal in relation to the other domains. However, these data are difficult to be compared since scores from other studies highlighted the importance of emotional and relational aspects for female sexual response. Thus, pregnancy is a period in which women can be even more susceptible to complaining of sexual dysfunction, as factors such as general emotional well-being and the feeling of closeness with the partner during intercourse are predictors of sexual problems, such as female desire (Soares, et al., 2020).

Among the domains of sexual function, the most affected was desire. Other studies also found the lowest mean in the domain "Desire" in pregnant women (Erbil, 2018). The physiological changes that occur during pregnancy, such as illness and sleepiness, as well as the change in body self-image that occurs from the second trimester, can lead to a reduction in the desire and, consequently, the arousal phase can also be impaired (De Araújo Mathias et al., 2015).

\section{Conclusion}

In the present study, it was possible to observe that the functional assessment of the pelvic floor in pregnant women shows significant deficiencies and limitations regarding the coordination, control, and activation of the PFM, in addition to muscle strength, where all participants used the accessory muscles.

Regarding the sexual function, there were low values ranging between 4.74 and 3.36 with higher scores for satisfaction, pain, orgasm and lubrication and lower scores for desire and arousal. The FSFI result indicates a possible dysfunction in this group, highlighting a possible hypoactivity of the sexual desire.

More studies with a larger number of pregnant women and greater methodological accuracy are suggested to highlight the relationship between the different types of this article.

\section{References}

Ashton-Miller, J. A., \& DeLancey, J. O. (2014). Functional anatomy of the female pelvic floor. Bridging science and clinical practice, 19-33. https://doi.org/10.1196/annals.1389.034

Baratella, T. M. P., Quiros, A. C. S., Veras, M. E. S., Alves, J. M. S., da Silva, T. S., Barros, M. D. L. N., \& de Carvalho, V. C. P. (2021). Prevalência de disfunções sexuais no puerpério de parto cesáreo. Research, Society and Development, 10 (9), e38810918143-e38810918143. https://doi.org/10.33448/rsdv10i9.18143

Barbosa, A. M. P., Carvalho, L. R. D., Martins, A. M. V. D. C., Calderon, I. D. M. P., \& Rudge, M. V. C. (2005). Efeito da via de parto sobre a força muscular do assoalho pélvico. Revista Brasileira de Ginecologia e Obstetrícia, 27, 677-682. https://doi.org/10.1590/S0100-72032005001100008

Barreto, K. L., Mesquita, Y. A., Junior, F. F. U. S., \& Gameiro, M. O. (2018). Treinamento da força muscular do assoalho pélvico e os seus efeitos nas disfunções sexuais femininas. Motricidade, 14(1), 424-427. https://www.proquest.com/docview/2059608604?pq-origsite=gscholar\&fromopenview=true

Costa, L. S., Santos, M. B. L., Pessoa, R. M. C., Nunes, R. A. O., de Araújo Sousa, I. P., da Silva, M. B., \& Santos, D. B. (2020). Avaliação do nível de conhecimento de gestantes sobre a função do assoalho pélvico e sexualidade. Research, Society and Development, 9 (9), e128997252-e128997252. http://dx.doi.org/10.33448/rsd-v9i9.7252

Da Silva Lima, L., Carmo, T. O. A., Neto, C. D. S. B., \& Cunha Pena, J. L. (2020). Sintomas depressivos em gestantes e violência por parceiro íntimo: um estudo transversal. Enfermería Global, 19(4), 1-45. https://doi.org/10.6018/eglobal.408841

De Araújo Mathias, A. E. R., Pitangui, A. C. R., Arantes, V. A., Vasconcelos, H. G., Vilela, F. M. F., \& Dias, T. G. (2015). Disfunção sexual: Avaliação de mulheres durante o terceiro trimestre gestacional. ABCS Health Sciences, 40(2). http://dx.doi.org/10.7322/abcshs.v40i2.734

Driusso, P., \& Beleza, A. C. S. (2018). Avaliação fisioterapêutica da musculatura do assoalho pélvico feminino. São Carlos: Editora Manole.

Erbil, N. (2018). Sexual function of pregnant women in the third trimester. Alexandria Journal of medicine, 54(2), 139-142. https://doi.org/10.1016/j.ajme.2017.03.004 
Franceschet, J., Sacomori, C., \& Cardoso, F. L. (2009). Força dos músculos do assoalho pélvico e função sexual em gestantes. Brazilian Journal of Physical Therapy, 13, 383-389. https://doi.org/10.1590/S1413-35552009005000054

Gosch, C. S., Pereira, I. B., \& Mundoco. L. S. (2020). Análise da percepção de puérperas sobre a assistência ao parto em uma maternidade do Tocantins. FEMINA, 48(7): 422 - 6. Disponível, em: https://docs.bvsalud.org/biblioref/2020/08/1117443/femina-2020-487-422-426.pdf

Hentschel, H., Alberton, D. L., Capp, E., Goldim, J. R., \& Passos, E. P. (2007). Validação do Female Sexual Function Index (FSFI) para uso em língua portuguesa. Revista HCPA. 27(1), 10-14. http://hdl.handle.net/10183/164528

Herbert, J. (2009). Pregnancy and childbirth: the effects on pelvic floor muscles. Nursing Times, 105(7), 38-41.

Laycock, J. O., \& Jerwood, D. (2001). Pelvic floor muscle assessment: the PERFECT scheme. Physiotherapy, 87(12), 631-642. https://doi.org/10.1016/S00319406(05)61108-X

Leite, A. P. L., Moura, E. D. A., Campos, A. A. S., Mattar, R., Souza, E. D., \& Camano, L. (2007). Validação do índice da função sexual feminina em grávidas brasileiras. Revista brasileira de ginecologia e obstetrícia, 29, 396-401. https://doi.org/10.1590/S0100-72032007000800003

Magno, L. D. P., Fontes-Pereira, A. J., \& Nunes, E. F. C. (2011). Avaliação quantitativa da função sexual feminina correlacionada com a contração dos músculos do assoalho pélvico. Revista Pan-Amazônica de Saúde, 2(4), 8-8. http://dx.doi.org/10.5123/S2176-62232011000400006

Marnach, M. L., Ramin, K. D., Ramsey, P. S., Song, S. W., Stensland, J. J., \& An, K. N. (2003). Characterization of the relationship between joint laxity and maternal hormones in pregnancy. Obstetrics \& Gynecology, 101(2), 331-335. https://doi.org/10.1016/s0029-7844(02)02447-X

Martinez, C. S., Ferreira, F. V., Castro, A. A., \& Gomide, L. B. (2014). Women with greater pelvic floor muscle strength have better sexual function. Acta obstetricia et gynecologica Scandinavica, 93(5), 497-502. https://doi.org/10.1111/aogs.12379

Negri, M. (2016). Avaliação da função sexual feminina entre adolescentes usuárias de método contraceptivo. https://repositorio.unifesp.br/handle/11600/46157

Pacagnella, R. D. C., Vieira, E. M., Rodrigues Jr, O. M., \& Souza, C. D. (2008). Adaptação transcultural do female sexual function index. Cadernos de Saúde Pública, 24, 416-426. https://doi.org/10.1590/S0102-311X2008000200021

Pechorro, P., Diniz, A., \& Vieira, R. (2009). Satisfação sexual feminina: Relação com funcionamento sexual e comportamentos sexuais. Análise psicológica, 27(1), 99-108. https://doi.org/10.14417/ap.187

Scagliusi, F. B., Polacow, V. O., Coelho, D., Philippi, S. T., Cordás, T. A., Alvarenga, M., \& Lancha Jr, A. H. (2005). Psychometric testing and applications of the Body Attitudes Questionnaire translated into Portuguese. Perceptual and motor skills, 101(1), 25-41. https://doi.org/10.2466/pms.101.1.25-41

Sherburn, M., \& Bø, K. (2005). Evaluation of female pelvic-floor muscle function and strengh. Phys. Ther, 85, $269-282$.

Silva, J. B. D. (2020). Reprodutibilidade da palpação unidigital e bidigital durante a avaliação da contração voluntária máxima do assoalho pélvico de mulheres de diferentes faixas etárias e validade de construto com a manometria. São Paulo. https://repositorio.ufscar.br/handle/ufscar/12400

Silva, J. B., de Godoi Fernandes, J. G., Caracciolo, B. R., Zanello, S. C., de Oliveira Sato, T., \& Driusso, P. (2021). Reliability of the PERFECT scheme assessed by unidigital and bidigital vaginal palpation. International. Urogynecology Journal, 1-9. https://doi.org/10.1007/s00192-020-04629-2

Slieker-ten Hove, M. C. P., Pool-Goudzwaard, A. L., Eijkemans, M. J. C., Steegers-Theunissen, R. P. M., Burger, C. W., \& Vierhout, M. E. (2009). Face validity and reliability of the first digital assessment scheme of pelvic floor muscle function conform the new standardized terminology of the International Continence Society. Neurourology and Urodynamics: Official Journal of the International Continence Society, 28(4), 295-300. https://doi.org/10.1002/nau.20659

Soares, P. R. A. L., Calou, C. G. P., Ribeiro, S. G., Aquino, P. D. S., Almeida, P. C. D., \& Pinheiro, A. K. B. (2020). Sexualidade em gestantes e fatores de risco associados. Revista Brasileira de Enfermagem, 73. https://doi.org/10.1590/0034-7167-2018-0786

Souza, E. L. B. L. (2002). Fisioterapia aplicada à obstetrícia: aspectos de ginecologia e neonatologia. Medsi.

Souza, M. M. M. B., de Vasconcelos, T. B., Pires, J. L. V. R., Macena, R. H. M., \& Bastos, V. P. D. (2016). Avaliação da força muscular do assoalho pélvico em profissionais do sexo na cidade de Fortaleza/CE. Fisioterapia Brasil, 17(6), 577-584. https://doi.org/10.33233/fb.v17i6.699

Sutter Latorre, G. F., Kracik Carmona, N., Aparecida Bilck, P., Berghmans, B., \& Flores Sperandio, F. (2015). Escores de corte para o FSFI. Revista Inspirar Movimento \& Saude, 7(1). https://www.inspirar.com.br/wp-content/uploads/2015/05/escores-Artigo_408-2014-2-1-1.pdf

Tibaek, S., \& Dehlendorff, C. (2014). Pelvic floor muscle function in women with pelvic floor dysfunction. International urogynecology journal, 25(5), 663669. https://doi.org/10.1007/s00192-013-2277-6

Tosun, G., Peker, N., Tosun, Ö. Ç., Yeniel, Ö. A., Ergenoğlu, A. M., Elvan, A., \& Yıldırım, M. (2019). Pelvic floor muscle function and symptoms of dysfunctions in midwifes and nurses of reproductive age with and without pelvic floor dysfunction. Taiwanese Journal of Obstetrics and Gynecology, 58(4), 505-513. https://doi.org/10.1016/j.tjog.2019.05.014

Vanelli, C., \& Silva, J. C. (2011). Sexo na gestação na percepção masculina. Psicologia. PT. https://www.psicologia.pt/artigos/textos/TL0253.pdf 